\title{
PENGARUH REWARD, INSENTIF, PEMBAGIAN TUGAS DAN PENGEMBANGAN KARIER PADA KEPUASAN KERJA PERAWAT DI RUMAH SAKIT ORTOPEDI PROF. DR. R. SOEHARSO SURAKARTA
}

\author{
Jimmy Fitria. ${ }^{1}$ Hunik Sri Runing Sawitri ${ }^{2}$ \\ PASCASARJANA, Universitas Sebelas Maret Surakarta, J1. Ir. Sutami 36 A Surakarta \\ Email: jimmy.fitria@yahoo.co.id
}

\begin{abstract}
The purpose of this study to analyze the influence of rewards, incentives, division of tasks and career development in the job satisfaction of nurses. This study was included in the category of ex-post facto research. This study used the individual (individual) for the unit of analysis, answer questions based on the responses of each individual (nurse Orthopaedic Hospital Prof. Dr. R. Soeharso Surakarta). The data used was primary and secondary data. The population in this study were nurses working in the Field of Nursing totaling 187 people and taken samples of 65 people with accidental sampling technique. The research instrument used a questionnaire with Likert scale. The data analysis includes validation test, reliability and multiple regression analysis. Test model assumptions including normality test, autocorrelation, multicollinearity and heteroscedasticity.

The results indicated that reward were positive and significant impact on job satisfaction of nurses, incentives were positive and significant impact on job satisfaction of nurses, division of tasks were positive and significant impact on job satisfaction of nurses, career development were positive and significant impact on job satisfaction of nurses, and the rewards, incentives, division of tasks and career development have a significant effect on job satisfaction of nurses at the hospital. Orthopedics Prof. Dr. R. Soeharso Surakarta.
\end{abstract}

Keywords: Reward, incentives, division tasks and career development, job satisfaction.

\begin{abstract}
Abstrak: Tujuan penelitian ini untuk menganalisis pengaruh reward, insentif, pembagian tugas dan pengembangan karier pada kepuasan kerja perawat. Penelitian ini termasuk dalam kategori penelitian ex-post facto. Penelitian ini menggunakan individu (individual) untuk unit analisisnya, jawaban pertanyaan berdasarkan tanggapan dari setiap individu (perawat Rumah Sakit Ortopedi Prof. Dr. R. Soeharso Surakarta). Jenis data yang digunakan adalah data primer dan sekunder. Populasi dalam penelitian ini adalah perawat yang bekerja di Bidang Keperawatan yang berjumlah 187 orang dan diambil sampel sejumlah 65 orang dengan teknik accidental sampling. Instrumen penelitian menggunakan kuesioner dengan skala likert. Analisa data meliputi uji validasi, reliabilitas dan analisa regresi berganda. Uji asumsi model meliputi uji normalitas, autokorelasi, multikolinearitas dan heteroskedastisitas. Hasil penelitian menunjukkan bahwa reward berpengaruh positif dan signifikan pada kepuasan kerja perawat, insentif berpengaruh positif dan signifikan pada kepuasan kerja perawat, pembagian tugas berpengaruh positif dan signifikan pada kepuasan kerja perawat, pengembangan karir berpengaruh positif dan signifikan pada kepuasan kerja perawat, dan reward, insentif, pembagian tuags dan pengembangan karir berpengaruh signifikan pada kepuasan kerja perawat di RS. Ortopedi Prof. Dr. R. Soeharso Surakarta.
\end{abstract}

Kata Kunci: Reward, insentif, pembagian tugas dan pengembangan karir, kepuasan kerja.

\section{PENDAHULUAN}

Sumberdaya manusia merupakan faktor yang sangat berharga, maka perusahaan bertanggungjawab untuk memelihara kualitas kehidupan kerja dan membina tenaga kerja agar bersedia memberikan kontribusinya secara optimal untuk mencapai tujuan perusahaan menurut Pruijt (2003). Era globalisasi yang semakin berkembang menuntut peningkatan mutu di segala sektor, tidak terkecuali dalam sektor pelayanan kesehatan. Rumah sakit 
sebagai salah satu instansi yang memberikan pelayanan kesehatan kepada masyarakat juga dituntut untuk memberikan pelayanan yang bermutu menurut Gibson et al.(2005). Peningkatan mutu pelayanan rumah sakit tidak terlepas dari peran berbagai disiplin tenaga kesehatan yang ada di rumah sakit termasuk perawat, karena sebagian besar pelayanan rumah sakit adalah pelayanan keperawatan.

Marquis et al.(2010) menyampaikan bahwa kualitas pelayanan keperawatan tidak hanya tergantung dari personel keperawatan saja tetapi juga tergantung dari dukungan pihak manajerial malalui fungsi manajemennya yang dimulai dari perencanaan,pengorganisasian,pe ngarahan dan pengawasan, sehingga mampu menciptakan organisasi yang memungkinkan pekerja tumbuh, meningkatkan motivasi dan produktivitas,menunjukan penghargaan yang positif terhadap pekerja,mengakui prestasi serta mendorong tercapainya kepuasan kerja. Kepuasan kerja perawat walaupun diyakini sangat menentukan terbentuknya kepuasan pasien yang berdampak besar terhadap mutu pelayanan keperawatan,namun belum semua rumah sakit mampu menciptakan suasana yang memotivasi dan meningkatkan produktivitas menurut Bustami (2011). Kepuasan kerja adalah rasa psikologis kepercayaan dan kepuasan untuk memenuhi kebutuhan pribadi, keinginan dan harapan dengan pekerjaan itu sendiri dan lingkungan kerja dan loyalitas untuk bekerja menurut Schultz et al. dalam Elarabi dan Johari (2014). Hasil penelitian Newman dan Taylor (2002) bagi perawat rumah sakit melakukan survei kuesioner dan menemukan dampak positif yang signifikan antara kepuasan kerja terhadap prestasi kerja Huang et al.(2014).

Fenomena di dunia menunjukkan bahwa tingkat kepuasan kerja perawat masih termasuk dalam kategori yang cukup rendah. Pada bulan Maret 2007 telah dilakukan penelitian pada 1.783 perawat di Amerika Serikat dan Kanada yang rata-rata adalah perawat yang sudah bekerja di rumah sakit selama lebih dari 15 tahun hasilnya menyatakan bahwa $23 \%$ cukup tidak puas, dan $9 \%$ sangat tidak puas. Aspek kepemimpinan perawat menempati ketidakpuasan yang paling besar yaitu $57 \%$ perawat tidak puas dengan gaya kepemimpinan yang ada menurut Clarke (2007). Isu rendahnya tingkat kepuasan dan motivasi kerja merupakan hal yang umum terjadi di negara berkembang,namun barubaru ini dari hasil penelitian internasional pada 43.000 perawat dari 700 rumah sakit di Amerika Serikat,Kanada,Inggris,Skotlan dia dan Jerman menunjukkan bahwa jumlah ketidakpuasan para perawat dengan pekerjaan mereka berkisar antara $17 \%$ di Jerman sampai $41 \%$ di Amerika Serikat menurut Aiken et al. (2001). Adanya persentase keinginan para perawat untuk meninggalkan kehadiran kerja mereka bervariasi dari $17 \%$ di Jerman sampai $39 \%$ di Inggris. Berdasarkan penelitian di Thailand tentang kepuasan kerja perawat dan persepsi mereka terhadap kepemimpinan kepala ruang di Rumah Sakit Provinsi Sakaeo,ditemukan bahwa kepuasan kerja perawat $13,79 \%$ yang masih rendah menurut shui hui wang et al.(2005).

Indonesia merupakan Negara berkembang dengan isu motivasi dan kepuasan kerja perawat yang tidak jauh berbeda. Sangat minimnya data statistik yang terkait menyebabkan sulitnya pantauan dan program pengembangan bagi sumberdaya manusia pada bidang keperawatan secara nasional. Hasil analisis lingkungan kerja perawat oleh WHO (2013) di beberapa negara Asia,termasuk Indonesia menemukan bahwa lingkungan kerja perawat belum optimal seperti pendapatan perawatan yang rendah, fasilitas kesehatan yang buruk dan tidak aman bagi staf perawat, rasio perawat pasien yang tidak optimal, hubungan tim kerja yang perlu penguatan, beberapa perawat mengalami kekerasan fisik, kurang perlindungan dalam pekerjaan dan beberapa fasilitas yang tidak memuaskan. Penelitian lain di Indonesia yang mendukung adalah Rochyatun (2011) yang menyatakan bahwa di sebuah rumah sakit di Jawa Tengah menunjukkan rendahnya tingkat kepuasan kerja perawat karena kurangnya penghargaan yang diberikan pada perawat, 
penghargaan tersebut tidak hanya dalam bentuk gaji atau upah yang diterima saja melainkan bentuk pujian dari kepala ruang, sehingga perawat memiliki motivasi kerja yang cukup rendah.

Salah satu motivatoryang dapat digunakan manajer untuk menciptakan motivasi dan meningkatkan produktivitas,namun sering terabaikan atau kurang dimanfaatkan adalah reward menurut Wibowo (2012). Reward merupakan salah satu faktor penting yang mempengaruhi individu bekerja pada suatu organisasi. Menurut Hasibuan (2010) penghargaan (reward) merupakan balasan jasa yang diberikan instansi pada tenaga kerja, penghargaan bukan sekedar hak dan kewajiban tetapi yang terpenting adalah daya dorong dan semangat untuk bekerja. Menurut Wibowo (2011) reward adalah tingkat penampilan yang diwujudkan melalui usaha tertentu, diyakini bahwa individu akan termotivasi oleh harapan yang akan datang,sehingga beberapa orang melakukan pekerjaannya dengan baik. Hasil penelitian Lambert dalam Sriratnaprapat dan Songwathana (2011) menunjukkan bahwa pengalaman dan faktor-faktor kepuasan kerja gaji,promosi,tunjangan dan imbalan kontingen yang ditemukan terkait positif dengan kepuasan kerja perawat.

Upaya yang dilakukan oleh sebuah instansi dalam memberikan motivasi kepada perawat yaitu dengan pemberian insentif. Pemberian insentif merupakan salah satu usaha untuk meningkatkan kualitas kerja perawat dan juga untuk memenuhi kebutuhan perawat. Perawat suatu rumah sakit akan bekerja lebih giat dan semangat sesuai dengan harapan rumah sakit,jika manajemen memperhatikan dan memenuhi kebutuhannya,baik kebutuhan yang bersifat materi maupun kebutuhan yang bersifat non materi (Zenah, 2014) Terry dalam Suwatno(2011) mengemukakan pendapat bahwa insentif merupakan sesuatu yang merangsang minat untuk bekerja.

Pekerjaan seorang perawat dalam memberikan pelayanan keperawatan tidak terlepas dari pengaturan jam kerja di suatu rumah sakit yang lebih dikenal dengan istilah shift kerja. Perawat dihadapkan dengan tugas kerja yang berbeda, berbeda dengan shift, terutama shift malam,kondisi kerja,situasi terkait stres,penderitaan dan kematian pasien menurut cooper dalam moustaka dan constantinidis(2010). Wijaya et al.(2006) manyatakan bahwa shift kerja berperan penting terhadap permasalahan pada manusia yang dapat meluas menjadi gangguan tidur, gangguan fisik dan psikologi dan gangguan sosial serta kehidupan keluarga. Shift juga dapat mempengaruhi beberapa perubahan fisik dan psikologi tubuh manusia diantaranya adalah kelelahan. Oleh karena itu,dibutuhkan pembagian tugas dalam bekerja.

Sunyoto (2012) mendefinisikan bahwa pembagian tugas merupakan penyusunan pekerjaan ke dalam kelas-kelas,kelompokkelompok, atau jenis-jenis berdasarkan rencana sistematika tertentu. Sastrohadiwiryo (2005) berpendapat bahwa pembagian tugas merupakan rincian pekerjaan yang berisi informasi menyeluruh tentang tugas atau kewajiban,tanggung jawab,dan kondisi-kondisi yang diperlukan apabila pekerjaan tersebut dikerjakan. Sunyoto (2012) menyebutkan manfaat pembagian yang intinya antara lain adalah klarifikasi tanggung jawab,evaluasi pekerjaan,penilaian kinerja,survei kompensasi,penempatan keluar. Mondy (2008) menyebutkan manfaat pembagian kerja adalah untuk mengetahui tugas utama yang harus dikerjakan, mengetahui waktu yang dialokasikan untuk setiap tugas,mengetahui standar kerja yang harus dicapai,mengetahui kondisi dan bahaya yang mungkin terjadi,mengetahui jumlah pekerja dan atasan mereka,mengetahui mesin yang digunakan dalam pekerjaan. Sastrohadiwiryo (2005) berpendapat bahwa manfaat pembagian kerja yang intinya adalah tenaga kerja dapat melaksanakan tugas dan tanggung jawabnya berdaya guna dan berhasil guna menuju profesionalisme dan produktivitas.

Perawatsebagaisalahsatutenagakesehatan di rumah sakit memegang peranan penting dalam upaya mencapai tujuan pembangunan kesehatan. Keberhasilan pelayanan kesehatan 
bergantung pada partisipasi perawat dalam memberikan perawatan yang berkualitas bagi pasien Potter dan Perry(2005). Jenjang karir profesional perawat merupakan sistem untuk meningkatkan kinerja dan profesionalisme,sesuai dengan bidang pekerjaan melalui peningkatan kompetensi. Pengembangan jenjang karir profesional yang sudah dikembangkan oleh berbagai sarana kesehatan masih kurang memperhatikan tuntutan dan kebutuhan profesi,serta belum dikaitkan dengan kompensasi atau sistem penghargaan. Dengan adanya sistem jenjang karir profesional perawat yang diterapkan di setiap sarana kesehatan,diharapkan kinerja perawat semakin meningkat,sehingga mutu pelayanan kesehatan juga meningkat.

Dampak lain dari adanya jenjang karir profesional adalah mengarahkan perawat untuk menekuni bidang keahlian ditempat kerjanya dan meningkatkan profesionalismenya menurut Direktorat Bina Pelayanan Keperawatan Departemen Kesehatan RI (2006). Sistem pengembangan karir menjadi bagian dari manajemen personal atau manajemen sumberdaya manusia dan merupakan hal utama pada setiap organisasi keperawatan. Berdasarkan hasil penelitian yang dilakukan oleh Hartini (2007) mengatakan bahwa sistem pengembangan karir berhubungan secara positif dan significant dengan kepuasan kerja.Ingersoll et al.(2002) melakukan survei acak-sampel untuk meminta perawat baik di pedesaan dan perkotaan (n $=1853$ ) tentang kepuasan kerja,komitmen organisasi,demografi,dan rencana karir masa depan. Bila dibandingkan dengan perawat perkotaan,perawat pedesaan lebih cenderung berencana untuk melakukan pengembangan karier dalam tahun depan,dan kurang puas dengan pekerjaan mereka Ingersoll et al. dalam Roberge(2009).

Penelitan yang dilakukan Gkorezis dan Petrdou (2012) menunjukkan studi empiris yang mengeksplorasi pengaruh penghargaan ekstrinsik,yaitu hubungan dengan atasan,hubungan dengan rekan kerja,keamanan kerja dan imbalan keuangan hasil (insentif). Secara psikologis perawat penelitian ini telah menunjukkan bahwa hubungan dengan atasan,hubungan dengan rekan kerja,keamanan kerja dan imbalan keuangan hasil dapat meningkatkan pemberdayaan psikologis perawat. Hubungan dengan atasan memiliki efek paling kuat pada konstruk ini. Sedangkan penelitian Dhurup et al.(2014) menunjukkan bahwa ada tiga faktor yang berhubungan dengan kepuasan kerja perawat,yaitu kebijakan dan lingkungan yang mendukung,hasil kerja dan manfaat dan imbalan. Analisis regresi menunjukkan bahwa manfaat dan imbalan adalah prediktor kunci dari pengembangan karir antara perawat. Perencanaan dan pengembangan intervensi penting di daerah ini dari perawat tempat kerja sehingga tingkat kepuasan kerja antara staf perawat dalam rumah sakit umum dapat ditingkatkan.

RS Ortopedi Prof DR R Soeharso Surakarta merupakan salah satu instansi di bidang pelayanan kesehatan pemerintah vertikal kementerian kesehatan RI yang berlokasi di kelurahan Pabelan,Kecamatan Kartasura,kabupaten Sukoharjo Propinsi Jawa Tengah yang memiliki visi menjadi rumah sakit ortopedi unggulan dengan pelayanan prima di ASEAN adapun salah satu misinya adalah mewujudkan Sumberdaya Manusia yang profesional ,inovatif dan kreatif. Oleh karena itu perlu untuk dilakukan pengukuran terhadap kepuasan kerja perawat melalui peningkatan dan pemanfaatan sumberdaya yang seoptimal mungkin sehingga menjadi sumberdaya manusia yang profesional.

Selain perihal tersebut yang melatarbelakangi penelitian ini adalah meneruskan penelitian yang pernah dilakukan oleh salah satu karyawan RS Ortopedi Prof DR R Soeharso Surakarta yang telah selesai menempuh pendidikan S2 MM di Universitas Muhamadiyah Surakarta pada tahun 2011 berjudul: Pengaruh Kompensasi,Motivasi Kerja,Komunikasi,Lingkungan dan Pengawasan terhadap Kepuasan Kerja Pegawai di RS Ortopedi Prof DR R Soeharso Surakarta bahwa hasil penelitian varibel 
tersebut berpengaruh positif dan signifikan pada kepuasan kerja pegawai,dan saran penelitian tersebut hendaknya kepuasan kerja dikaitkan dengan reward,insentif,pembagian tugas dan pengembangan karier,berdasarkan uraian diatas peneliti tertarik untuk melakukan penelitian yang berjudul pengaruh reward,insentif,pembagian tugas dan pengembangan karier pada kepuasan kerja perawat di Rumah Sakit Ortopedi Prof DR R Soeharso Surakarta.

Berdasarkanlatarbelakangmasalahdiatas, permasalahan peneliti ini dapat dirumuskan 1) Apakah reward berpengaruh pada kepuasan kerja perawat?, Apakah insentif berpengaruh pada kepuasan kerja perawat?, Apakah pembagian tugas berpengaruh pada kepuasan kerja perawat?, Apakah pengembangan karier berpengaruh pada kepuasan kerja perawat?, Apakah reward, insentif, pembagian tugas dan pengembangan karier secara simultan berpengaruh pada kepuasan kerja perawat?

Secara khusus ada lima tujuan yang ingin dicapai, yaitu: Menganalisis pengaruh reward pada kepuasan kerja perawat; Menganalisis pengaruhinsentifpadakepuasan kerjaperawat., Menganalisis pengaruh pembagian tugas pada kepuasan kerja perawat, Menganalisis pengaruh pengembangan karier pada kepuasan kerja perawat, Menganalisis reward, insentif, pembagian tugas dan pengembangan karier secara simultan berpengaruh pada kepuasan kerja perawat.

\section{TINJAUAN PUSTAKA}

\section{Kepuasan Kerja}

Kepuasan kerja didefinisikan sebagai fungsi dari hubungan yang dirasakan antara apa yang diinginkan dari pekerjaan seseorang dan apa yang merasakan itu menawarkan,dipengaruhi oleh keadaan unik seseorang seperti kebutuhan,nilai-nilai dan harapan Daulatram (2003). Kepuasan kerja adalah fungsi kompleks dari sejumlah variabel. Seseorang dapatdipenuhidengan satuataulebih aspek atau pekerjaannya tetapi pada saat yang sama tidak senang dengan hal-hal lain yang berkaitan dengan pekerjaan menurut Ghazali et al.(2007). Ada aspek yang berbeda untuk kepuasan kerja: kepuasan kerja merupakan respon emosional terhadap situasi pekerjaan; kepuasan kerja ditentukan oleh seberapa baik menyebabkan hasil-hasil memenuhi atau melebihi harapan; dan itu mewakili beberapa sikap terkait seperti yang diminta oleh pekerjaan itu sendiri,bayar,kesempatan promosi,supervisi dan integrasi rekan kerja Moodley dan Coopoo(2006). Penting untuk konsep kepuasan kerja adalah sikap,emosi dan perasaan tentang pekerjaan dan bagaimana sikap,emosi dan perasaan mempengaruhi pekerjaan dan kehidupan individu menurut Carrim et al.(2006).

Willem et al.(2007) mendefinisikan kepuasan kerja dalam dua kategori; dari pendekatan global dan pendekatan faktor. kepuasan kerja global yang didefinisikan sebagai perasaan dan emosi karyawan menghasilkan berdasarkan pengalaman kerja mereka atau lingkungan kerja menurut Lepoko et al.(2006). Kepuasan kerja dari pendekatan faktor menekankan sikap karyawan untuk aturan,rekan-rekan dan lingkungan organisasi menurut Pietersen (2005). Vroom (1964; 1995) menemukan bahwa kepuasan kerja berhubungan langsung dengan hasil reward yang dirasakan dalam bentuk gaji,prospek promosi,interaksi dengan rekan kerja, kesempatan untuk mempengaruhi keputusan,dan karyawan kontrol atas pekerjaan mereka. Dia mengembangkan teori subtraktif pada motivasi untuk bekerja dan dari pandangan bahwa kepuasan kerja berbanding terbalik dengan perbedaan antara apa kebutuhan individu dari pekerjaan, dan apa yang disediakan oleh pekerjaan dalam hal kebutuhan.

Menurut As'ad (2005: 105) kepuasan kerja merupakan hal yang bersifat individual. Setiap individu akan memiliki tingkat kepuasan yang berbeda- beda sesuai dengan sistem nilai nilai yang berlaku pada dirinya. Ini disebabkan karena adanya perbedaan pada masing - masing individu. Semakin banyak aspek - aspek dalam pekerjaan yang sesuai 
dengan keinginan individu tersebut,maka semakin tinggi tingkat kepuasan yang dirasakan dan sebaliknya

Banyak faktor yang mempengaruhi kepuasan kerja karyawan . faktor faktor itu sendiri dalam peranannya memberikan kepuasan kerja kepada karyawan tergantung pada pribadi masing masing karyawan . Faktor faktor yang memberikan kepuasan kerja As'ad (2005 : 115) sebagai berikut : 1) Faktor individual meliputi : umur,kesehatan,watak dan harapan 2) Faktor sosial meliputi hubungan kekeluargaan,pandangan masyarakat, kesempatan berekreasi,kegiatan perserikatan pekerja,kebebasan berpolitik dan hubungan kemasyarakatan 3) Faktor utama dalam pekerjaan meliputi : upah,pengawasan,ketentraman kerja,kondisi kerja dan kesempatan untuk maju. Selain itu juga penghargaan terhadap kecakapan,hubungan sosial di dalam pekerjaan,ketetapan dalam menyelesaikan konflik antar manusia, perasaan diperlakukan adil baik yang menyenagkan pribadi maupun tugas.

Menurut Sopiah ( 2008 : 170) kepuasan kerja merupakan suatu ungkapan emosional yang bersifat positif atau menyenangkan sebagai hasil dari penilaian terhadap suatu pekerjaan atau pengalama kerja. Kepuasan kerja merupakan sikap umum seorang karyawan terhadap pekerjaannya.

Menurut Sopiah ( 2008 : 171) faktor faktor yang berpengaruh terhasap kepuasan kerja adalah kesempatan untuk promosi,faktor intrinsik, kondisi kerja,pendidikan,usah pribadi,sistem gaji,jam kerja,hakikat pekerjaan,kesempatan untuk maju atau berkembang

Kepuasan kerja merupakan salah satu elemen yang cukup penting dalam organisasi. Hal ini disebabkan kepuasan kerja dapat mempengaruhi perilaku kerja seperti malas,rajin,produktif dan lain- lain atau mempunyai hubungan dengan beberapa jenis perilaku yang sangat penting dalam organisasi Hariandja (2007 : 290) faktor faktor yang mempengaruhi kepuasan kerja yang berkaitan dengan beberapa aspek Hariandja (2007:290) : a) gaji yaitu jumlah bayaran yang diterima seseorang sebagai akibat dari pelaksanaan kerja apakah sesuai dengan kebutuhan dan dirasakan adil b) pekerjaan itu sendiri yaitu isi pekerjaan yang dilakukan seseorang apakah memiliki elemen yang memuasakan c) rekan sekerja yaitu teman teman kepada siapa seseorang senantiasa berinteraksi dalam pelaksanaan pekerjaan. Seseorang dapat merasakan rekan kerjanya sangat menyenangkan atau tidak menyenangkan d) atasan yaitu seseorang yang senantiasa memberi perinatah atau petunjuk dalam pelaksanaan tugas. Cara cara atasan dapat tidak menyenangkan bagi seseorang atau menyenangkan dan hal ini dapat mempengaruhi kepuasankerja;e) promosiyaitu kemungkinan seseorang dapat berkembang melalui kenaikan jabatan. Seseorang dapat merasakan adanya kemungkinan yang besar untuk naik jabatan atau tidak,proses kenaikan jabatan kurang terbuka atau tebuka. Ini juga dapat mempengaruhi tingkat kepuasan kerja seseorang f) lingkungan kerja yaitu lingkungan fisik dan psikologis

Kepuasan kerja adalah perasaan dan emosi karyawan terhadap pekerjaan mereka,seseorang dengan tingkat kepuasan kerja yang tinggi berpikir positif terhadap pekerjaan sedang yang tidak puas memegang perasaan negatif tentang pekerjaan,kepuasan kerja penting karena memiliki dampak terhadap perilaku organisasi. Dengan kepuasan karyawan dapat menyediakan informasi untuk meningkatkan faktor seperti produktifitas,loyalitas dan kepuasan kerja sehingga organisasi dapat mengidentifikasi akar penyebab dan menciptakan perbaikan kepuasan kerja Locke (1976) ,menurut hulin dan Judge ( 2003) kepuasan kerja termasuk multidimensi respon psikologis dari pekerjaan dan termasuk respon berpikir (evaluasi), effektif atau emosi dan komponen perilaku.

\section{Reward}

Reward adalah salah satu kebijakan manajemen sumberdaya manusia inti bertujuan motivasi karyawan. Reward dapat 
dibagi menjadi dua kategori: intrinsik dan ekstrinsik. Reward ekstrinsik yang dihasilkan dari tindakan orang lain, seperti supervisor,dan dikendalikan oleh manajer; sedangkan intrinsik kurang nyata dan berasal dari orang atau pekerjaan itu sendiri menurut Beardwell dan Holden(1994). Salah satu hubungan yang paling penting dikembangkan di tempat kerja adalah antara atasan dan karyawan. Dari Human Relations era School,ada penekanan pada jenis hubungan. Hubungan positif dengan supervisor mereka dapat menyebabkan karyawan untuk memiliki sikap positif terhadap organisasi mereka. Terutama di sektor tersier,hal ini diklaim bahwa mendukung hubungan dengan supervisor dan manajer dapat membantu bawahan membalas terhadap pelanggan menurut Peccei dan Rosenthal (2001). Mengenai pemberdayaan psikologis,ada beberapa studi yang mengeksplorasi hubungan antara hubungan yang mendukung dan yang baik dengan atasan dan pemberdayaan psikologis menurut Sparrowe (1994).

Menurut Siagian (2011) reward diukur berdasarkan pada sistem finansial,promosi,pengembangan diri dan hubungan kerja. Finansial bukan hanya dilihat dari segi materi saja,namun pujian atau pengakuan yang diberikan atasan ataupun reward dalam bentuk lain dapat meningkatkan kepuasan kerja,selain itu gaji juga merupakan determinan penting dalam kepuasan kerja karena merupakan alat untuk memenuhi kebutuhan yang akan dapat ditukar dengan barang dan jasa. Gibson (2005) menambahkan selain upah dan gaji penghargaan finansial juga dapat berupa jaminan sosial seperti program pensiun,asuransi kesehatan dan liburan dan biasanya tidak berdasarkan kinerja namun berdasarkan senioritas atau masa kerja.

Promosi dalam kesempatan peningkatan pangkat dan jabatan perlu dalam meningkatkan kepuasan kerja karena setiap karyawan pasti berkeinginan mendapatkan promosi pekerjaan yang lebih baik. Dengan demikian pihak manajer harus mempertimbangkan pemberian promosi yang adil dan pengembangan program promosi yang baik karena promosi adalah jenjang kenaikan pegawai yang dapat menimbulkan kepuasan secara pribadi dan kebanggaan juga merupakan harapan terhadap perbaikan dalam penghasilan. Promosi dalam kesempatan peningkatan pangkat dan jabatan perlu dalam meningkatkan kepuasan kerja karena setiap karyawan pasti berkeinginan mendapatkan promosi pekerjaan yang lebih baik.

Setiap pegawai mendambakan promosi karena dipandang sebagai penghargaan atas keberhasilan seseorang yang dapatmenunjukan prestasi kerja yang tinggi dalam menjalankan pekerjaannya Wibowo ( 2011). Hal ini juga menunjukkan adanya pengembangan diri pada perawat. Motivasi perawat dalam hal pengembangan diri sangat bagus namun belum didukung oleh kebijakan rumah sakit dimana perawat pelaksana masih merasakan dukungan rumah sakit dalam hal pendanaan maupun immaterial belum memadai. Kondisi ini apabila tidak ditanggapi dengan baik oleh manajerial rumah sakit dapat menurunkan motivasi bekerja staf yang akhirnya nanti akan berujung pada rasa frustasi dan tentunya akan mempunyai dampak munculnya rasa ketidakpuasan.

Hubungan kerja akan memberikan dampak positif terhadap kepuasan kerja karena hubungan kerja dapat mengisi kebutuhan akan interaksi sosial, rekan kerja yang baik dan mendukung akan menghantarkan pada kepuasan kerja yang meningkat. Selain rekan kerja hubungan dengan atasan juga merupakan determinan utama kepuasan. Friedrich (2001) dalam Marquis dan Huston (2010) menyatakan cara komunikasi manajer lini pertama terhadap pegawai mempengaruhi sikap pegawai terhadap kepuasan,biasanya manajer tersebut mempunyai pengaruh yang lebih besar dibanding level manajer lainnya. Studi lain Kerfoot (2001) dalam Maruqis dan Huston (2010), menyatakan bahwa kepuasan karyawan ditingkatkan bila penyelia langsung bersifat ramah dan dapat memahami, menawarkan pujian untuk kinerja yang baik,mendengarkan pendapat karyawan 
dan menunjukan suatu minat pribadi mereka. Dengan demikian, jelas bahwa hubungan interpersonal antara pegawai dan penyelianya sangat penting, oleh karena itu manajer dapat menciptakan suasana yang menunjukkan penghargaan yang positif terhadap pegawai, mendorong komunikasi yang terbuka, mengakui prestasi dan mendorong pertumbuhan dan produktivitas yang dapat menghasilkan kepuasan menurut Marquis dan Huston (2010).

\section{Insentif}

Insentif adalah bentuk imbalan atau balas jasa yang diberikan oleh suatu organisasi atau perusahaan kepada pegawai dalam bentuk materi(material insentif) maupun dalam bentuk kepuasan rohani(non material insentif). Insentif merupakan bentuk lain dan imbalan langsung diluar gaji yang merupakan imbalan tetap,biasanya sistem ini diutamakan sebagai strategi untuk meningkatkan produktifitas pegawai. Insentif atau bonus merupakan salah satu cara untuk meningkatkan motivasi kerja dan kinerja pegawai Ruky(2012).

Upaya yang dilakukan oleh sebuah instansi dalam memberikan motivasi kepada perawat yaitu dengan pemberian insentif. Pemberian insentif merupakan salah satu usaha untuk meningkatkan kualitas kerja perawat dan juga untuk memenuhi kebutuhan perawat. Perawat suatu rumah sakit akan bekerja lebih giat dan semangat sesuai dengan harapan rumah sakit,jika manajemen memperhatikan dan memenuhi kebutuhannya, baik kebutuhan yang bersifat materi maupun kebutuhan yang bersifat non materi Zenah (2014) Terry dalam Suwatno (2011), mengemukakan pendapat bahwa insentif merupakan sesuatu yang merangsang minat untuk bekerja.

\section{Pembagian Tugas}

Sunyoto(2012)mendefinisikanpembagian tugas merupakan penyusunan pekerjaan ke dalam kelas-kelas,kelompok-kelompok,atau jenis-jenis berdasarkan rencana sistematika tertentu. Sastrohadiwiryo (2005) berpendapat bahwa pembagian tugas merupakan rincian pekerjaan yang berisi informasi menyeluruh tentang tugas/kewajiban, tanggung jawab, dan kondisi-kondisi yang diperlukan apabila pekerjaan tersebut dikerjakan. Sunyoto (2012) menyebutkan manfaat pembagian yang intinya antara lain adalah klarifikasi tanggung jawab,evaluasi pekerjaan, penilaian kinerja,survei kompensasi,penempatan keluar. Mondy (2008) menyebutkan manfaat pembagian kerja adalah untuk mengetahui tugas utama yang harus dikerjakan,mengetahui waktu yang dialokasikan untuk setiap tugas, mengetahui standar kerja yang harus dicapai,mengetahui kondisi dan bahaya yang mungkin terjadi,mengetahui jumlah pekerja dan atasan mereka,mengetahui mesin yang digunakan dalam pekerjaan. Sastrohadiwiryo (2005) berpendapat bahwa manfaat pembagian kerja yang intinya adalah tenaga kerja dapat melaksanakan tugas dan tanggung jawabnya berdaya guna dan berhasil guna menuju profesionalisme dan produktivitas.

Manurut Hasibuan (2010) pembagian tugas dalam pekerjaan adalah menguraikan: 1) Identifikasi pekerjaan atau jabatan yaitu memberikan nama jabatan. 2) Hubungan tugas dan tanggung jawab yakni perincian tugas dan tanggung jawab secara nyata diuraikan secara terpisah agar jelas diketahui. 3) Standar wewenang dan pekerjaan yakni kewenangan dan prestasi yang harus dicapai harus jelas. 4) Syarat kerja harus diuraikan secara jelas. 5) Ringkasan pekerjaan atau jabatan hendaknya menguraikan bentuk umum pekerjaan dengan mencantumkan fungsi-fungsi dan tugas utamanya. 6) Penjelasan tugas yakni harus dijelaskan jabatan awal dan jabatan akhir.

\section{Pengembangan Karier}

Perawatsebagaisalahsatutenagakesehatan di rumah sakit memegang peranan penting dalam upaya mencapai tujuan pembangunan kesehatan. Keberhasilan pelayanan kesehatan bergantung pada partisipasi perawat dalam memberikan perawatan yang berkualitas bagi pasien Potter dan Perry (2005). Pengembangan karir profesional perawat 
merupakan sistem untuk meningkatkan kinerja dan profesionalisme sesuai dengan bidang pekerjaan melalui peningkatan kompetensi. Pengembangan jenjang karir profesional yang sudah dikembangkan oleh berbagai sarana kesehatan masih kurang memperhatikan tuntutan dan kebutuhan profesi, serta belum dikaitkan dengan kompensasi atau sistem penghargaan. Dengan adanya sistem jenjang karir profesional perawat yang diterapkan di setiap sarana kesehatan,diharapkan kinerja perawat semakin meningkat, sehingga mutu pelayanan kesehatan juga meningkat. Dampak lain dari adanya jenjang karir profesional adalah mengarahkan perawat untuk menekuni bidang keahlian ditempat kerjanya dan meningkatkan profesionalismenya Direktorat Bina Pelayanan Keperawatan Departemen Kesehatan RI (2006). Sistem pengembangan karir menjadi bagian dari manajemen personal atau manajemen sumberdaya manusia dan merupakan hal utama pada setiap organisasi keperawatan. Berdasarkan hasil penelitian yang dilakukan oleh Hartini (2007) mengatakan bahwa sistem pengembangan karir berhubungan secara positif dan significant dengan kepuasan kerja.

Sistem pengembangan karir profesional perawatmeliputi tiga aspek yang saling ber hubungan,yaitukinerja,orientasi profesional dan kepribadian perawat serta kompetensi yang menghasilkan kinerja profesional. Perawat profesional diharapkan mampu berpikir rasional,mengakomodasi kondisi lingkungan,mengenal diri sendiri,belajar dari pengalaman dan mempunyai aktualisasi diri sehingga dapat meningkatkan jenjang karir profesinya. Jenjang karir perawat dapat dicapai melalui pendidikan formal dan pendidikan berkelanjutan berbasis kompetensi serta pengalaman kerja di sarana kesehatan Depkes ( 2006).

\section{Pengembangan Hipotesis}

\section{Pengaruh Reward Pada Kepuasan} Kerja Perawat

Reward merupakan salah satu faktor penting yang mempengaruhi individu bekerja pada suatu organisasi. Menurut Hasibuan (2010), penghargaan (reward) merupakan balasan jasa yang diberikan instansi pada tenaga kerja,penghargaan bukan sekedar hak dan kewajiban tetapi yang terpenting adalah daya dorong dan semangat untuk bekerja. Menurut Wibowo (2011) reward adalah tingkat penampilan yang diwujudkan melalui usaha tertentu,diyakini bahwa individu akan termotivasi oleh harapan yang akan datang sehingga beberapa orang melakukan pekerjaannya dengan baik. Berdasarkan hal itu,maka dirumuskan hipotesis penelitian sebagai berikut:

$\mathrm{H}_{1}$ : Reward berpengaruh positif pada kepuasan kerja perawat.

\section{Pengaruh Insentif pada Kepuasan Kerja Perawat}

Motivasi kepada perawat yaitu dengan pemberian insentif. Pemberian insentif merupakan salah satu usaha untuk meningkatkan kualitas kerja perawat dan juga untuk memenuhi kebutuhan perawat. Perawat suatu rumah sakit akan bekerja lebih giat dan semangat sesuai dengan harapan rumah sakit,jika manajemen memperhatikan dan memenuhi kebutuhannya,baik kebutuhan yang bersifat materi maupun kebutuhan yang bersifat non materi Zenah (2014) Terry dalam Suwatno (2011) mengemukakan pendapat bahwa insentif merupakan sesuatu yang merangsang minat untuk bekerja. Berdasarkan hal itu,maka dirumuskan hipotesis penelitian sebagai berikut:

$\mathrm{H}_{2}$ : Insentif berpengaruh positif pada kepuasan kerja perawat.

\section{Pengaruh Pembagian Tugas Pada Kepuasan Kerja Perawat}

Sunyoto (2012) mendefinisikan bahwa pembagian tugas merupakan penyusunan pekerjaan ke dalam kelas-kelas,kelompokkelompok,atau jenis-jenis berdasarkan rencana sistematika tertentu. Sastrohadiwiryo (2005) berpendapat bahwa pembagian 
tugas merupakan rincian pekerjaan yang berisi informasi menyeluruh tentang tugas/kewajiban,tanggung jawab,dan kondisi-kondisi yang diperlukan apabila pekerjaan tersebut dikerjakan. Sunyoto (2012) menyebutkan manfaat pembagian yang intinya antara lain adalah klarifikasi tanggung jawab,evaluasi pekerjaan,penilaian kinerja,survei kompensasi,penempatan keluar. Mondy (2008) menyebutkan manfaat pembagian kerja adalah untuk mengetahui tugas utama yang harus dikerjakan,mengetahui waktu yang dialokasikan untuk setiap tugas, mengetahui standar kerja yang harus dicapai,mengetahui kondisi dan bahaya yang mungkin terjadi,mengetahui jumlah pekerja dan atasan mereka, mengetahui mesin yang digunakan dalam pekerjaan.

Berdasarkan hal itu,maka dirumuskan hipotesis penelitian sebagai berikut:

$\mathrm{H}_{3}$ : Pembagian tugas berpengaruh positif pada kepuasan kerja perawat.

\section{Pengaruh Pengembangan Karier Pada Kepuasan Kerja Perawat}

Jenjang karir profesional perawat merupakan sistem untuk meningkatkan kinerja dan profesionalisme sesuai dengan bidang pekerjaan melalui peningkatan kompetensi. Pengembangan jenjang karir profesional yang sudah dikembangkan oleh berbagai sarana kesehatan masih kurang memperhatikan tuntutan dan kebutuhan profesi serta belum dikaitkan dengan kompensasi atau sistem penghargaan. Dengan adanya sistem jenjang karir profesional perawat yang diterapkan di setiap sarana kesehatan,diharapkan kinerja perawat semakin meningkat,sehingga mutu pelayanan kesehatan juga meningkat. Dampak lain dari adanya jenjang karir profesional adalah mengarahkan perawat untuk menekuni bidang keahlian ditempat kerjanya dan meningkatkan profesionalismenya Direktorat Bina Pelayanan Keperawatan Departemen Kesehatan RI (2006). Sistem pengembangan karir menjadi bagian dari manajemen personal atau manajemen sumberdaya manusia dan merupakan hal utama pada setiap organisasi keperawatan. Berdasarkan hasil penelitian yang dilakukan oleh Hartini (2007) mengatakan bahwa sistem pengembangan karir berhubungan secara positif dan significant dengan kepuasan kerja. Berdasarkan hal itu,maka dirumuskan hipotesis penelitian sebagai berikut:

\section{$\mathrm{H}_{4}$ : Pengembangan karier berpengaruh positif pada kepuasan kerja perawat.}

\section{Pengaruh Reward,Insentif,Pembagian Tugas dan Pengembangan Karier Pada Kepuasan Kerja Perawat}

Robbins (2008) mendefinisikan kepuasan kerja sebagai sikap umum terhadap pekerjaan seseorang yang menunjukkan perbedaan antara jumlah penghargaan yang diterima pekerja dan jumlah yang mereka yakini seharusnya mereka terima. Mathis dan Jackson (2009) menyatakan bahwa kepuasan kerja adalah keadaan emosi yang positif dari mengevaluasi pengalaman kerja seseorang. Sunyoto (2012) menjelaskan bahwa kepuasan kerja adalah keadaan emosional yang menyenangkan atau tidak menyenangkan di mana para karyawan memandang pekerjaannya". Mangkunegara (2009) menyatakan bahwa kepuasan kerja berhubungan dengan variabel-variabel seperti turnover,tingkat absensi,umur,tingkat pekerjaan,dan ukuran organisasi perusahaan. Sunyoto (2012) mengemukakan kepuasan kerja berhubungan dengan absensi,perputaran tenaga kerja,produktifitas,kecelakaan kerja, labourturnover dan sebagainya. Berdasarkan hal itu,maka dirumuskan hipotesis penelitian sebagai berikut:

$\mathrm{H}_{5}$ : Reward, insentif,pembagian tugas dan pengembangan karier berpengaruh positif pada kepuasan kerja perawat.

\section{METODE PENELITIAN}

Penelitian ini termasuk dalam kategori penelitian ex-post facto yaitu suatu penelitian yang dilakukan untuk meneliti peristiwa yang 
telah terjadi dan kemudian merunut kebelakang untuk mengetahui faktor-faktor yang dapat menyebabkan timbulnya kejadian tersebut Sugiyono (2009). Penelitian ini juga bersifat asosiatif kausal yaitu penelitian yang mencari pengaruh sebab akibat dari variabel yang akan diteliti.. Penelitian ini menggunakan individu (individual) untuk unit analisisnya, jawaban pertanyaan berdasarkan tanggapan dari setiap individu (perawat Rumah Sakit Ortopedi Prof. Dr. R. Soeharso Surakarta). Jenis data yang digunakan adalah data primer dan sekunder. Populasi dalam penelitian ini adalah perawat yang bekerja di Bidang Keperawatan yang berjumlah 187 orang dan diambil sampel sejumlah 65 orang dengan teknik accidental sampling. Instrumen penelitian menggunakan kuesioner dengan skala likert. Analisa data meliputi uji validasi, reliabilitas dan analisa regresi berganda. Uji asumsi model meliputi uji normalitas, autokorelasi, multikolinearitas dan heteroskedastisitas. Uji Hipotesis menggunakan analisis regresi linier berganda. Regresi linier berganda

\section{HASIL DAN PEMBAHASAN}

\section{Hasil Penelitian}

Berdasarkan hasil analisis regresi berganda pengaruh reward, insentif,pembagian tugas dan pengembangan karier pada kepuasan kerja perawat di RS Ortopedi Prof DR R Soeharso Surakarta dapat diketahui hasilnya seperti tampak pada Tabel 1.

Tabel 1. Rekapitulasi Hasil Analisis Regresi

\begin{tabular}{lrrrrr}
\multicolumn{7}{c}{ Berganda } \\
\hline Variabel & $\begin{array}{c}\text { Unstandarized } \\
\text { Coefficients B }\end{array}$ & $\begin{array}{l}\text { Std. } \\
\text { Error }\end{array}$ & Beta & $\mathrm{t}_{\text {hitmg }}$ & Prob. \\
\hline Konstanta & 8,750 & 4,496 & - & 1,946 & 0,056 \\
Reward $\left(\mathrm{X}_{1}\right)$ & 0,453 & 0,139 & 0,322 & 3,255 & 0,002 \\
Insentif $\left(\mathrm{X}_{2}\right)$ & 0,513 & 0,185 & 0,299 & 2,767 & 0,008 \\
Pembagian Tugas $\left(\mathrm{X}_{3}\right)$ & 0,438 & 0,178 & 0,229 & 2,468 & 0,016 \\
Pengembangan karier $\left(\mathrm{X}_{4}\right)$ & 0,376 & 0,157 & 0,183 & 2,395 & 0,028 \\
\hline$F_{\text {hitimg }}$ & $17,462 * *$ & & & & \\
Signifikan & 0,000 & & & & \\
$\mathrm{R}$ Square & 0,538 & & & & \\
Adj. R Square & 0,507 & & & & \\
\hline
\end{tabular}

Sumber: Hasil pengolahan data, 2016.
Berdasarkan Tabel I. dapat diketahui hasil uji signifikan secara parsial bahwa variabel reward, insentif, pembagian tugas dan pengembangan karier berpengaruh positif dan signifikan pada variabel kepuasan kerja perawat di RS Ortopedi Prof. Dr. R. Soeharso Surakarta. Uji ini dilakukan untuk mengetahui signifikansi pengaruh tiap-tiap variabel independen yaitu reward, insentif, pembagian tugas dan pengembangan karier yang baik akan dapat meningkatkan kepuasan kerja perawat di RS. Ortopedi Prof. Dr. R. Soeharso Surakarta. Berdasarkan hasil analisis dapat diuraikan pengaruh tiap-tiap variabel independen terhadap variabel dependen sebagai berikut:

1. Pengaruh reward $\left(\mathrm{X}_{1}\right)$ pada kepuasan kerja perawat

Hasil analisis regresi diperoleh nilai $t_{\text {hitung }}$ sebesar 3,255 $>\mathrm{t}_{\text {tabel }}(2,042)$ dengan nilai probabilitas $(\mathrm{r}=0,002)<0,05$ berarti $\mathrm{H}_{1}$ didukung, artinya bahwa ada pengaruh yang signifikan antara reward terhadap kepuasan kerja perawat di RS. Ortopedi Prof. Dr. R. Soeharso Surakarta, adapun besarnya pengaruh reward pada kepuasan kerja perawat sebesar 0,453 , artinya jika reward meningkat maka kepuasan kerja perawat meningkat.

2. Pengaruh insentif $\left(\mathrm{X}_{2}\right)$ pada kepuasan kerja perawat

Hasil uji-t diperoleh nilai $\mathrm{t}_{\text {hitung }}$ sebesar $2,767>t_{\text {tabel }}(2,042)$ dengan nilai probabilitas $(\mathrm{r}=0,008)<0,05$ berarti $\mathrm{H}_{2}$ didukung, artinya bahwa ada pengaruh yang signifikan antara insentif terhadap kepuasan kerja perawat di RS. Ortopedi Prof. Dr. R. Soeharso Surakarta, adapun besarnya pengaruh antara insentif pada kepuasan kerja perawat sebesar 0,513 , artinya jika insentif meningkat maka kepuasan kerja perawat meningkat.

3. Pengaruh pembagian tugas $\left(\mathrm{X}_{3}\right)$ pada kepuasan kerja perawat

Hasil uji-t diperoleh nilai $\mathrm{t}_{\text {hitung }}$ sebesar $2,468>t_{\text {tabel }}(2,042)$ dengan nilai probabilitas $(\mathrm{r}=0,016)<0,05$ berarti $\mathrm{H}_{3}$ didukung, artinya bahwa ada pengaruh 
yang signifikan antara pembagian tugas pada kepuasan kerja pada perawat di RS. Ortopedi Prof. Dr. R. Soeharso Surakarta, adapun besarnya pengaruh antara pembagian tugas pada kepuasan kerja perawat sebesar 0,438 , artinya jika pembagian tugas meningkat maka kepuasan kerja perawat meningkat

4. Pengaruh pengembangan karier $\left(\mathrm{X}_{4}\right)$ pada kepuasan kerja perawat

Hasil uji-t diperoleh nilai $t_{\text {hitung }}$ sebesar $2,395>t_{\text {tabel }}(2,042)$ dengan nilai probabilitas $(\mathrm{r}=0,028)<0,05$ berarti $\mathrm{H}_{4}$ didukung, artinya bahwa ada pengaruh yang signifikan antara pengembangan karier pada kepuasan kerja perawat di RS. Ortopedi Prof. Dr. R. Soeharso Surakarta, adapun besarnya pengaruh antara pengembangan karier pada kepuasan kerja perawat sebesar 0,376 , artinya jika pengembangan karier meningkat maka kepuasan kerja perawat meningkat

Berdasarkan hasil analisis tersebut terbukti bahwa hipotesis yang menyatakan "ada pengaruh yang signifikan variabel independen (reward, insentif, pembagian tugas dan pengembangan karier) pada variabel dependen (kepuasan kerja perawat) di RS. Ortopedi Prof. Dr. R. Soeharso Surakarta secara parsial", terbukti kebenarannya.

Berdasarkan hasil uji F pada Tabel IV.16. didapatkan $\mathrm{F}_{\text {hitung }}>\mathrm{F}_{\text {tabel }} ; 17,462>2,760$ dan nilai sign. $0,000<0,05$ maka Ho ditolak dan $\mathrm{H}_{\mathrm{a}}$ diterima, hal ini berarti variabel reward, insentif, pembagian kerja dan pengembangan karier berpengaruh signifikan terhadap variabel terikat yaitu kepuasan kerja perawat di di RS. Ortopedi Prof. Dr. R. Soeharso Surakarta.

Berdasarkan hasil analisis koefisien derterminasi (Adjusted-R ${ }^{2}$ ) diperoleh angka sebesar 0,507 , artinya bahwa $50,70 \%$ variasi variabel kepuasan kerja perawat dapat dijelaskan oleh variabel reward, insentif, pembagian tugas dan pengembangan karier, sedangkan sisanya yaitu $49,30 \%$ merupakan variabel yang tidak diteliti dalam penelitian ini

\section{PEMBAHASAN HASIL PENELITIAN}

\section{Pengaruh reward pada kepuasan kerja perawat}

Berdasarkan pengujian hipotesis dengan analisis regresi berganda diketahui nilai sign. $0,002<0,05$, maka hipotesis pertama $\left(\mathrm{H}_{1}\right)$ didukung, artinya ada pengaruh positif dan signifikan reward pada variabel kepuasan kerja perawat.

Reward merupakan salah satu faktor penting yang mempengaruhi individu bekerja pada suatu organisasi. Menurut Hasibuan (2010), penghargaan (reward) merupakan balasan jasa yang diberikan instansi pada tenaga kerja, penghargaan bukan sekedar hak dan kewajiban tetapi yang terpenting adalah daya dorong dan semangat untuk bekerja. Menurut Wibowo (2011) reward adalah tingkat penampilan yang diwujudkan melalui usaha tertentu, diyakini bahwa individu akan termotivasi oleh harapan yang akan datang, sehingga beberapa orang melakukan pekerjaannya dengan baik. Hasil penelitian ini didukung oleh hasil penelitian sebelumnya yang dilakukan oleh Sriratnaprapat dan Songwathana (2011) menunjukkan bahwa pengalaman dan faktor-faktor kepuasan kerja gaji,promosi,tunjangan dan imbalan kontingen yang ditemukan terkait positif dengan kepuasan kerja perawat. Hasil analisis pengaruh reward pada kepuasan kerja perawat membuktikan bahwa RS Ortopedi Prof DR R Soeharso Surakarta telah memberikan reward sesuai dengan kinerja perawat yang mampu meningkatkan kepuasan kerja perawat.

\section{Pengaruh insentif terhadap kepuasan kerja perawat}

Berdasarkan pengujian hipotesis dengan analisis regresi berganda diketahui nilai sign. $0,008<0,05$, maka hipotesis kedua $\left(\mathrm{H}_{2}\right)$ didukung, artinya ada pengaruh positif dan signifikan insentif pada kepuasan kerja perawat. Hal ini berarti semakin baik dan meningkat dari insentif yang diterima perawat maka semakin meningkat pula kepuasan kerja perawat tersebut. 
Insentif adalah bentuk imbalan atau balas jasa yang diberikan oleh suatu organisasi atau perusahaan kepada pegawai dalam bentuk materi(material insentif) maupun dalam bentuk kepuasanrohani(non material insentif). Insentif merupakan bentuk lain dan imbalan langsung diluar gaji yang merupakan imbalan tetap, biasanya sistem ini diutamakan sebagai strategi untuk meningkatkan produktifitas pegawai. Insentif atau bonus merupakan salah satu cara untuk meningkatkan motivasi kerja dan kinerja pegawai Ruky(2012).

\section{Pengaruh pembagian tugas terhadap kepuasan kerja perawat}

Berdasarkan pengujian hipotesis dengan analisis regresi berganda diketahui nilai sign. $0,016<0,05$, maka hipotesis ketiga $\left(\mathrm{H}_{3}\right)$ didukung, artinya ada pengaruh positif dan signifikan pembagian tugas pada variabel kepuasan kerja perawat.

Sunyoto (2012) mendefinisikan pembagian tugas merupakan penyusunan pekerjaan ke dalam kelas-kelas,kelompokkelompok atau jenis-jenis berdasarkan rencana sistematika tertentu. Manurut Hasibuan (2010) pembagian tugas dalam pekerjaan adalah menguraikan: 1) Identifikasi pekerjaan atau jabatan, yaitu memberikan nama jabatan. 2) Hubungan tugas dan tanggung jawab,yakni perincian tugas dan tanggung jawab secara nyata diuraikan secara terpisah agar jelas diketahui. 3) Standar wewenang dan pekerjaan,yakni kewenangan dan prestasi yang harus dicapai harus jelas. 4) Syarat kerja harus diuraikan secara jelas. 5) Ringkasan pekerjaan atau jabatan, hendaknya menguraikan bentuk umum pekerjaan dengan mencantumkan fungsi-fungsi dan tugas utamanya. 6) Penjelasan tugas, yakni harus dijelaskan jabatan awal dan jabatan akhir

Pengaruh pengembangan karir terhadap kepuasan kerja perawat

Berdasarkan Berdasarkan pengujian hipotesis dengan analisis regresi berganda diketahui nilai sign. $0,028<0,05$, maka hipotesis keempat $\left(\mathrm{H}_{4}\right)$ didukung, artinya ada pengaruh positif dan signifikan pengembangan karir pada variabel kepuasan kerja perawat.

Pengembangan karir profesional perawat merupakan sistem untuk meningkatkan kinerja dan profesionalisme sesuai dengan bidang pekerjaan melalui peningkatan kompetensi.Sistem pengembangan karir profesional perawat meliputi tiga aspek yang saling berhubungan,yaitu kinerja, orientasi profesional dan kepribadian perawat,serta kompetensi yang menghasilkan kinerja profesional menurut Potter dan Perry(2005).

\section{KESIMPULAN}

Berdasarkan pada penyajian hasil penelitian serta pembahasan hasil penelitian, maka dapat disimpulkan:

1. Reward berpengaruh positif dan signifikan pada kepuasan kerja perawat di RS. Ortopedi Prof. Dr. R. Soeharso Surakarta.

2. Insentif berpengaruh positif dan signifikan pada kepuasan kerja perawat di RS. Ortopedi Prof. Dr. R. Soeharso Surakarta.

3. Pembagian tugas berpengaruh positif dan signifikan pada kepuasan kerja perawat di RS. Ortopedi Prof. Dr. R. Soeharso Surakarta.

4. Pengembangan karir berpengaruh positif dan signifikan pada kepuasan kerja perawat di RS. Ortopedi Prof. Dr. R. Soeharso Surakarta.

5. Reward, insentif, pembagian tuags dan pengembangan karir berpengaruh signifikan pada kepuasan kerja perawat di RS. Ortopedi Prof. Dr. R. Soeharso Surakarta.

\section{Saran}

Berdasarkan hasil analisis dan kesimpulan yang telah dilakukan, maka saran - saran yang dapat dikemukakan adalah:

1. Kepada pimpinan dan karyawan

Untuk meningkatkan kepuasan kerja perawat di RS Ortopedi Prof DR R Soeharso Surakarta ,maka 
pimpinan perlu memperhatikan reward,insentif,pembagian tugas dan pengembangan karier perawat dengan baik sehingga mampu menghasilkan perawat yang berkinerja baik serta mempunyai kepuasan kerja yang tinggi yang pada akhirnya mampu meningkatkan mutu pelayanan rumah sakit antara lain dengan melihat mean dari variabel yaitu :

a. Pada variabel reward dapat dilihat bahwa nilai mean terendah ada pada pertanyaan saya merasa puas dengan kualitas dan kuantitas reward yang diberikan yang berarti bahwa perawat masih belum puas dengan reward yang telah diberikan rumah sakit, hal ini perlu dipertimbangkan rumah sakit untuk memberikan reward yang lebih kepada perawat agar memiliki semangat dan daya dorong yang lebih untuk bekerja misalnya dengan hubungan yang baik dan mendukung atasan dengan bawahan,kesempatan mendapatkan promosi yang baik dan adil,balasan jasa perlu ditingkatkan dalam hal ini adalah materi diluar gaji dan insentif

b. Pada variabel insentif dapat dilihat mean paling rendah adalah pertanyaan insentif hanya diberikan kepada karyawan yang berprestasi yang berarti insentif diberikan kepada semua perawat baik yang berprestasi atau yang tidak berprestasi. Agar perawat rumah sakit bekerja lebih giat dan semangat sesuai harapan rumah sakit maka manajemen perlu memperhatikan pemberian insentif selama ini perlu dibedakan besaran insentif untuk karyawan berprestasi dan tidak berprestasi dan pimpinan memperhatikan kebutuhan perawat baik berupa materi maupun non materi

c. Pada variabel pembagian tugas nilai mean terendah pada item pertanyaan pembagian tugas menjadikan pekerjaan lebih bervariasi dan tidak monoton yang berarti bahwa perawat menilai pembagian tugas perawat belum bervariasi dan masih monoton hal ini perlu ditingkatkan pimpinan agar perawat dapat melaksanakan tugas dan tanggung jawabnya agar berdaya guna dan berhasil guna menuju profesionalisme dan produktifitas dengan lebih memperjelas pembagian tugas agar mengetahui tugas utama yang harus dikerjakan, mengetahui waktu yang dialokasikan dalam setiap tugas, mengetahui standar kerja yang harus dicapai, mengetahui kondisi dan bahaya yang mungkin terjadi,mengetahui jumlah pekerja dan atasan mereka,mengetahui mesin yang akan digunakan mondy(2008)

d. Variabel pengembangan karier dengan nilai mean terendah adalah pada item pertanyaan rumah sakit membahas rencana karier dengan perawat sebelum keputusan diambil untukkebaikanmersama, yang berarti perawat selama ini belum dilibatkan secara langsung dalam perencanaan karier sebelum keputusan diambil,untuk meningkatkan kinerja dan profesionalisme pimpinan perlu melibatkan perawat secara langsung dalam pengembangan karier seperti dalam pendidikan formal dan pendidikan berkelanjutan berbasis kompetensi

e. Pada variabel kepuasan kerja perawat item pertanyaan dengan nilai mean terendah adalah saya membutuhkan pekerjaan lain untuk mendapatkan peran profesional dalam bekerja yang berarti perawat dirumah sakit dalam mendapatkan peran profesional dirumah sakit masih membutuhkan pekerjaan lain. Hal ini perlu diperhatikan oleh pimpinan agar kepuasan kerja perawat dapat optimal misalnya dengan melihat faktor pekerjaan 
dengan lebih memperhatikan jenis pekerjaan, struktur organisasi, pangkat(golongan) kedudukan, mutu pengawasan,jaminanfinansi al,kesempatn promosi jawabatan , interaksi sosial, hubungan kerja hasil penelitian mangkunegara ( 2009)

2. Kepada peneliti akan datang

Kepada Peneliti akan datang disarankan agar melakukan penelitian terkait dengan kepuasan kerja perawat atau karyawan dengan menggunakan variabel bebas selain variabel yang sudah diteliti dalam penelitian ini,misalnyafaktor kepemimpinan,karakteristik individu.

\section{DAFTAR PUSTAKA}

Arikunto, Suharsimi. 2006. Prosedur Penelitian Suatu Pendekatan Praktik. Jakarta : Rineka Cipta.

As'ad, Moh .2005. Teori Ilmu Sumber Daya Manusia, Psikologi Industri, Yogyakarta : Liberty

Beardwell, I. and Holden L. 1994. Human Resource Management: Acontemporary perspective. Pitman Publishing.

Budiyono. 2004. Statistika untuk Penelitian. Surakarta: Sebelas Maret University Press.

Bustami. 2011. Penjaminan Mutu Pelayanan Kesehatan dan Akseptabilitasnya, Jakarta: Erlangga.

Carrim, N., Basson, J., \& Coetzee, M. 2006. The relationship between job satisfaction and locus of control in a South African call centreenvironment. Journal of Labour Relations, Vol 30 No 2,Hal. 6681.

Daulatram, B.L. 2003. Organisational culture and job satisfaction. Journal of Business \& Industrial Marketing, Vol 18 No 3,Hal 219-236.

Dhurup, M., et al. 2014. Factors Influencing
Job Satisfaction and Its Relationship on Career Development Among Nursing Staff within a Public Hospital in South Africa. Mediterranean Journal of Social Sciences, Vol 5 No 13.

Elarabi, Hasan Mohamed dan Johari, Fuadah. 2014. The Determinant Factors Effecting the Job Satisfaction and Performance in Libyan Government Hospital. Asian Social Science, Vol. 10, No. 8.

Ghazali, S.S., Shah, I.A, Zaidi, S.A.A., \&Tahii, M.H .2007. Job Satisfaction Among Doctors Working at Teaching Hospital of Bahawalpur, Pakistan. Journal of Ayub Medical College Abbottabad, Vol 19 No 3,Hal 42-45.

Ghozali, Imam .2006. Analisis Multivariate Dengan Program SPSS, Badan Penerbit Universitas Diponegoro.

Gibson, James L. John, M. Ivancevich dan James H. Donnelly, Jr. 2005. Organization. Boston: McGraw-Hill Companies, Inc.

Gkorezis, Panagiotis dan Petridou, Eugenia. 2012.The impact of extrinsic rewards on nurses' psychological empowerment: the case of Health Care in Greece. Department of Economics, Aristotle University, Greece.

Wang, Shu,H, et al. 2003.Job Satisfaction off staff nurse and their perception on head hurses leadership Journal of PublicHealth and Development,Vol.11, No.1.

Hair, J.F., R. Anderson R.E., Tatham, R.L. and Black, W. C.1998., Multivariate Data Analysis, Prentice-Hall, International, London.

Hariandja, Marihot Tua Effendi .2007. Manajemen Sumber Daya Manusia, Jakarta : PT Gramedia Widiasarana Indonesia

Hartini, Tien. 2007. Keperawatan Komunitas: Upaya Memandirikan Masyarakat untuk 
Hidup Sehat. Jakarta: Trans Info Media.

Hasibuan, SP. 2010. Manajemen Sumberdaya Manusia, Edisi revisi. Jakarta: Bumi Aksara

Hidayat, A. Alimul. 2007. Metode Penelitian Kebidanan Dan Tehnik Analisis Data. Surabaya: Salemba.

Huang, Su-Ming. Et al. 2014. A Study of the Effect of Incentive System on Job Performance-Locus of Control as a Moderator. The Journal of International Management Studies, Vol.9, No.1

Hulin, C. L., \& Judge, T. A. 2003. Job attitudes. In W. C. Borman, D. R. ligen, \&

R.J.Klimoski(Eds.), Handbook psychology industrial and organizational

psychology Hal 255-276. Hoboken, NJ: Wiley.

Laschinger, H.K.S., Purdy N., and Almost J.2007. "The impact of Leader-Member Exchange Quality, Empowerment, and Core Self evaluation on NurseManager's Job Satisfaction", Journal of Nursing Administration, Vol.37, No.5, hal 221 229.

Lepoko, C.S.P., Bezuidenhout, M.C., \& Roos, J.H. 2006.Organisational climate as a cause of job dissatisfaction among nursing staff inselected hospitals within the Mpumalanga Province. Curationis, Vol.29, No.1, hal 28-36.

Liden, R., Wayne, S. and Sparrowe R. 2000. "An examination of the mediation role of psychological empowerment on the relations between the job, interpersonal relationships, and work outcomes", Journal of Applied Psychology, Vol.85, No.3, hal 407 - 416

Locke,E.A.1976.The Nature and Causes of job satisfaction, in M.D Dunnette (Ed) handbook of Industrial and organization psychology hal. 1297-1349 chicago : Rand Mc Nally.
Mardalis. 2008. Metode Penelitian (Suatu Pendekatan Proposal). Jakarta: Bumi. Aksara.

Marquis, BL \& Huston, C.J. 2010. Leadership, Roles and management Function in Nursing: Theory and application. 3 ed. Philadelphia: Lippincott.

Mangkunegara, Anwar Prabu. 2009. Manajemen Sumberdaya Manusia Perusahaan. Bandung: PT. Remaja Rosdakarya.

Mathis, Robert L dan Jackson, John H. 2009. Manajemen Sumberdaya Manusia Buku I. Terjemahan oleh Jimmy Sadeli dan Bayu Prawira Hie. Jakarta: Salemba Empat.

Mondy, R. Wayne. 2005. Mananjemen Sumberdaya Manusia Jilid 1. Terjemahan oleh Bayu Airlangga. 2008. Jakarta: Erlangga.

Moodley, P., \&Coopoo, Y. 2006. Job Satisfaction of Self Employed Trainers and Personal Trainers Employed at Co mmercialGymnasiums:AComparative Study. Journal of Research in Sport, Vol.28, No.2,hal. 105-112.

Moustaka,E., dan Constantinidis,T.C.2010. Sources and effects of work-related stress in nursing. Health Science journal, vol.4, No.4,hal.210-216

Nursalam. 2003. Konsep \& Penerapan Metodologi Penelitian Ilmu Keperawatan: Pedoman Skripsi, Tesis, dan Instrumen Penelitian Keperawatan. Jakarta. Salemba Medika.

Notoatmodjo, S. 2010. Metodologi Penelitian Kesehatan. Jakarta : Rineka Cipta.

Peccei, R. \& Rosenthal P. 2001.Delivering customer oriented behavior through empowerment: an empirical test of HRM assumptions", Journal of ManagementStudies, Vol.38, No.6, hal.831- 857 . 
Pedoman pengembangan jenjang karier profesional perawat.2006. Direktorat Bina Pelayanan Keperawatan Direktorat Jendral Bina Pelayanan Medik Departemen Kesehatan RI

Potter, P.A, Perry, A.G.2005. Buku Ajar Fundamental Keperawatan : Konsep, Proses, dan Praktik.Edisi 4.Volume 2.Alih Bahasa : Renata Komalasari,dkk. Jakarta:EGC.

Pietersen, C. 2005. Job satisfaction of hospital nursing staff. Journal of Human Resources Management, Vol.3, No. 2,hal. 19-25.

Pruijt, Hans. 2003. Performance and Quality of Work Life, Journal of Organizational Change Management. Vol. 13, hal. 389-400.

Robbins, Stephen P. 2008. PrinsipPrinsip Perilaku Organisasi Edisi Kelima. Terjemahan oleh Halida dan Dewi Sartika. Jakarta: Erlangga.

Ruky, A. S. 2012. Manajemen Penggajian dan Pengupahan untuk Karyawan Perusahaan.

Roberge, Candice Manahan. 2009. Who Stays in Rural Nursing Practice? An International Review of The Literacture on Factors Influencing Rural Nurse Retention. Online Journal of Rural Nursing and Health Care, vol. 9, no. 1.

Sastrohadiwiryo, Siswanto. 2005. Manajemen Tenaga Kerja Indonesia. Jakarta: PT Bumi Aksara.

Sriratnaprapat, Jarurat dan Songwathana, Praneed. 2011. Nurses' Job Satisfaction within the Context of Asian Cultures: A Concept Analysis. Pacific Rim Int J Nurs Res.Vol. 15 No. 1

Sekaran, Uma, 2006. Metodologi Penelitian Untuk Bisnis, Jakarta: Salemba Empat.

Sopiah, 2008, Perilaku Organisasi, Yogyakarta : Penerbit Andi
Sparrowe, R. T. 1994. "Empowerment in the hospitality industry: Anexploration of antecedents and outcomes", Hospitality Research Journal, Vol.17, No.3, hal.5173.

Sugiyono.2009. Metode Penelitian Bisnis, Bandung : Alfabeta.

Sunyoto, Danang. 2012. Manajemen Sumberdaya Manusia. Yogyakarta: CAPS (Center for Academic Publishing Service)

Suwatno. 2011. Manajemen SDM dalam Organisasi Publik dan Bisnis. Alfabeta. Bandung.

Vroom, V.H. .1964. Work and Motivation. (1st ed.). New York: John Wiley and Sons, Inc.

Vroom, V.H.1995. Work and motivation. San Francisco: Jossey-Bass.

Wibowo, .2011. Manajemen Kinerja, Ed. 3 Jakarta: Rajawali Press.

Willem, A., Buelens, M., \& De Jonghe, I. 2007 . Impact of Organisational Structure on nurses' job satisfaction: A questionnaire survey.International Journal of Nursing Studies, Vol. 44, No.6,hal.1011-1020.

WHO.2003. Nursing and Midwifery Workforce Management, Analysis of country Assesment, New delhi:WHO Regional Office For South East Asia

Wijaya, Maurits, L.S dan Suparniati, E.2006. Hubungan antara shift kerja dengan gangguan tidur dan kelelahan kerja perawat instalasi rawat darurat Rumah Sakit Dr. Sardjito Yogyakarta, Sains Kesehatan, Vol.19, No.2 hal 235 -245

Zenah, Syarifah Nur. 2014. Hubungan Pemberian Insentif dengan Motivasi Kerja Perawat Ruang Rawat Inap Kelas III RSUD Inche Abdul Moeis Samarinda. E Journal Administrasi Negara, 2014, Vol.3 No.2, hal. 451- 463. 